\title{
ANALISIS FAKTOR YANG BERPENGARUH TERHADAP TINGKAT UNDERPRICING PERUSAHAAN MANUFAKTUR DI BURSA EFEK INDONESIA PERIODE 1996-2015
}

\author{
Purwanti $^{1}$, Eddy Irsan Siregar ${ }^{2}$ \\ ${ }^{1}$ Pelita Bangsa University, Email : yleavi@yahoo.com \\ ${ }^{2}$ Pascasarjana Universitas Muhammadiyah Jakarta, Email: siregareddy@ gmail.com
}

\begin{abstract}
Go Public or better known as IPO (Initial Public Offering) is an activity undertaken by the company in the framework of the initial public offering of stock sales. In the IPO process there is a phenomenon called Underpricing. Underpricing is a phenomenon where the offer price in the primary market is lower than the closing price in the secondary market. This study aims to analyze the factors that influence the level of Underpricing. Sampling research using purposive sampling method of the population of 57 manufacturing companies who conduct an IPO in the period January 1996 - December 2015, and obtained samples for research as many as 35 companies. This study uses seven (7) variables, namely Company Size, Percentage of Shares Offered, Return on Equity (ROE), Earning Per Share (EPS), Debt to Equity Ratio (DER), Inflation Rate and Interest Rate (BI Rate). Data analysis was done by multiple linear regression method and using SPSS software. The results of multiple regression model analysis show that firm size, percentage of stocks offered, EPS, ROE, Inflation rate, and BI Rate have no influence on underpricing level. While DER has an effect on the level of significance of $2.1 \%$ to the level of underpricing of manufacturing companies that conduct IPO period January 1996 - December 2015.
\end{abstract}

Keywords: IPO, Underpricing, Company Size, Percentage of Shares Offered, ROE, EPS, DER, Inflation, BI Rate

\section{PENDAHULUAN}

Berdasarkan

Undang-Undang

Nomor 8 Tahun 1995, Pasar Modal didefinisikan sebagai kegiatan yang bersangkutan dengan Penawaran Umum dan Perdagangan Efek, Perusahaan Publik yang berkaitan dengan Efek yang diterbitkannya, serta lembaga dan profesi yang berkaitan dengan Efek. Dengan adanya pasar modal, pihak yang memiliki kelebihan dana dapat menyalurkan dana tersebut melalui instrumen investasi di Pasar Modal dengan harapan memperoleh imbal hasil atau keuntungan (return), sedangkan pihak yang memerlukan dana dapat memanfaatkan dana dari investor melalui penerbitan instrumen investasi Pasar Modal dan menggunakan dana tersebut untuk melakukan pengembangan usaha. Menjual saham kepada publik melalui Pasar Modal ini disebut juga dengan Go Public. Dalam proses Go Public sebelum saham diperdagangkan di pasar sekunder (Bursa Efek), terlebih dahulu saham perusahaan yang akan Go Public dijual di pasar perdana (primary market) yang biasa disebut IPO / Initial Public Offering (Jogiyanto, 2003:29).

Harga saham yang dijual di pasar perdana (saat IPO) telah ditentukan terlebih dahulu atas kesepakatan antara emiten dengan pelaksana penjamin emisinya (underwriter), sedangkan harga di pasar sekunder ditentukan oleh mekanisme pasar (penawaran dan permintaan), dengan kata lain harga saham terbentuk dari supply dan demand antar investor atas saham tersebut. Dalam dua mekanisme penentuan harga tersebut sering terjadi perbedaan harga terhadap 
saham yang sama antara pasar perdana dan pasar sekunder. Apabila penentuan harga saham saat IPO secara signifikan lebih rendah dibandingkan dengan harga yang terjadi di pasar sekunder pada hari pertama, maka terjadi apa yang disebut dengan underpricing (Suyatmin dan Sujadi, 2006). Sebaliknya, apabila harga saat IPO secara signifikan lebih tinggi dibandingkan dengan harga yang terjadi di pasar sekunder pada hari pertama, gejala ini disebut dengan overpricing .

$$
\text { Beatty dan Ritter (1986) }
$$

mengungkapkan bahwa underpricing pada pasar perdana disebabkan oleh karena adanya informasi asimetris antara emiten dan underwriter, maupun antar investor. Oleh karena itu, investor akan bereaksi terhadap informasi yang relevan, jadi ketika investor mengetahui adanya informasi baru yang akan mempengaruhi nilai fundamental saham, maka mereka akan melakukan penawaran pada harga tinggi saat informasi bagus (good news) dan penawaran pada harga rendah saat informasi buruk (bad news).

Fenomena underpricing juga terjadi di pasar modal berbagai negara, diantaranya Amerika Serikat (Ritter, 1991); Kuala Lumpur (Ranko dkk, 1988); Korea (Kim dkk, 1993); Hongkong (Mc Guinnes, 1992); Australia (How, 1995 dan Lee dkk, 1996) dalam Diyah Rachmawati (2007); China, Australia, Inggris dan Indonesia. Penelitian dari Suad Husnan (1996) dalam Diyah Rachmawati (2007) menunjukkan bahwa pada perusahaan privat maupun BUMN di Indonesia mengalami underpricing.

Beberapa penelitian sejenis tentang faktor-faktor yang menyebabkan underpricing memang sudah banyak dilakukan. Daljono (2000) mengembangkan penelitian Trisnawati dengan memperluas periode penelitian berdasarkan data tahun 1990-1997 di BEJ menemukan bahwa reputasi penjamin emisi dan financial leverage berpengaruh positif signifikan pada initial return. Anggita dan Gunasti (2012) menggunakan sampel penelitian sebanyak 74 perusahaan yang IPO pada periode 2007-2011 dan mendapatkan hasil bahwa variabel ROE mempengaruhi tingkat Underpricing secara signifikan sebesar 5\%, sedangkan DER dan tingkat inflasi tidak mempengaruhi tingkat Underpricing. Aulya (2014) menggunakan sampel penelitian sebanyak 38 perusahaan yang IPO pada periode 2011-2013 dan mendapatkan hasil bahwa variabel ukuran perusahaan, persentase saham yang ditawarkan, EPS, dan DER tidak berpengaruh terhadap tingkat Underpricing. Kukuh (2015) menggunakan sampel penelitian sebanyak 39 perusahaan yang IPO pada periode 2008-2012 dan mendapatkan hasil bahwa variabel ukuran perusahaan, ROE, dan DER tidak berpengaruh terhadap tingkat Underpricing.

Selain variabel-variabel keuangan dan non-keuangan, penulis juga bermaksud melakukan penelitian terhadap variabel makroekonomi, yaitu tingkat inflasi dan tingkat suku bunga (BI rate).

Inflasi yang tinggi menyebabkan harga barang naik secara umum. Kondisi ini berpengaruh terhadap biaya produksi dan harga jual barang, yang akan semakin tinggi. Inflasi yang tinggi menyebabkan menurunnya keuntungan suatu perusahaan, sehingga menyebabkan efek ekuitas menjadi kurang kompetitif (ang, 1997). Harga jual yang tinggi dan menurunnya daya beli masyarakat akan mempengaruhi profitabilitas perusahaan. Profitabilitas perusahaan yang menurun akan berdampak pada minat investor terhadap investasi saham yang ikut menurun. Akibatnya jika harga saham menjadi turun maka harga saham di awal 
akan menjadi lebih tinggi atau menjadi overpriced.

Tingkat suku bunga ditetapkan oleh Bank Indonesia untuk menjaga kestabilan ekonomi nasional. Penetapan tingkat suku bunga yang dilakukan Bank Indonesia akan mempengaruhi tingkat bunga perbankan nasional. Hal ini akan mempengaruhi masyarakat (investor) dalam menentukan pilihan investasinya. Meningkatnya tingkat bunga simpanan dan deposito di perbankan akan membuat masyarakat cenderung menyimpan uangnya di bank. Dampaknya perdagangan di pasar modal akan mengalami penurunan permintaan karena masyarakat yang beralih ke perbankan. Menurut Sunariyah (2004:22) meningkatnya tingkat bunga akan meningkatkan harga kapital sehingga memperbesar biaya perusahaan, sehingga terjadi perpindahan investasi dari saham ke deposito atau fixed investasi lainnya. Jika suku bunga naik, maka akan memberikan pengaruh negatif terhadap pasar ekuitas (Robert Ang, 1997:19.11).

Berdasarkan hal-hal itulah maka penulis bermaksud melakukan penelitian lebih lanjut mengenai faktor-faktor keuangan, non-keuangan, dan kondisi makroekonomi yang menyebabkan underpricing dengan menggunakan perusahaan sektor manufaktur sebagai objek penelitian, dengan harapan mendapatkan hasil penelitian yang berbeda dari penelitian-penelitian sebelumnya.

Dipilihnya sektor industri manufaktur karena diantara sektor lainnya, sektor manufaktur merupakan sektor yang harga sahamnya tidak terlalu dipengaruhi oleh kondisi ekonomi global. Industri manufaktur merupakan penopang utama perkembangan industri di sebuah negara. Perkembangan industri manufaktur di sebuah negara juga dapat digunakan untuk melihat perkembangan secara nasional di negara tersebut.

Data yang diolah dari www.idx.co.id, www.ticmi.co.id, dan www.bi.go.id, pada periode tahun 1996 2015, perusahaan manufaktur di Indonesia yang melakukan IPO berjumlah 57 perusahaan dan yang mengalami underpricing berjumlah 35 perusahaan.

\section{TINJAUAN PUSTAKA}

Definisi pasar modal (Tandelilin E., 2001) adalah pertemuan antara pihak yang memiliki kelebihan dana dengan pihak yang membutuhkan dana dengan cara memperjual-belikan sekuritas.

Instrumen pasar modal yang lazim diperdagangkan disebut efek yang memiliki umur lebih dari satu tahun yang meliputi saham, obligasi, sertifikat deposito, dan surat penggantian atau bukti sementara dari surat-surat tersebut.

Terdapat dua jenis pasar yang ada di Pasar Modal Indonesia (Darmadji, 2001), yaitu: a). Pasar Perdana adalah jenis pasar pada pasar modal dimana saham dan sekuritas lainnya dijual pertama kali pada masyarakat (penawaran umum) sebelum saham dan sekuritas tersebut dicatatkan di bursa. Kegiatan ini disebut penawaran umum perdana (Initial Public Offering). Harga saham di pasar perdana ditentukan oleh emiten dan penjamin emisi (underwriter) berdasarkan faktor-faktor fundamental dan faktor lain yang perlu diidentifikasi. b). Pasar Sekunder yaitu proses jual beli sekuritas emiten oleh dan antar investor untuk mendapatkan keuntungan. Harga saham di pasar ini ditentukan oleh permintaaan dan penawaran yang dipengaruhi berbagai faktor internal seperti Earning Per Share (EPS) atau kebijakan deviden dan faktor eksternal seperti kebijakan moneter dan inflasi. Pasar sekunder di Indonesia 
memperdagangkan saham biasa, saham preferen, obligasi, obligasi konversi, waran, bukti right, dan reksadana. Perdagangan di pasar sekunder dapat dilakukan di dua jenis pasar, yaitu pasar lelang (auction market) dan pasar negosiasi (negotiated market).

$$
X \text { Perusahaan yang }
$$

membutuhkan dana dapat melakukan penerbitan surat berharga seperti saham (stock), obligasi (bond), dan sekuritas lainnya. Surat berharga yang baru dijual dapat berupa penawaran perdana ke publik (initial public offering atau IPO) atau tambahan surat berharga baru jika perusahaan sudah go public. IPO merupakan kegiatan yang dilakukan perusahaan dalam rangka penawaran umum penjualan saham perdana (Ang, 1997). Setelah saham dijual di pasar perdana kemudian saham tersebut didaftarkan di pasar sekunder (listing). Dengan mendaftarkan saham tersebut di bursa, saham tersebut mulai dapat diperdagangkan di bursa efek bersama dengan efek yang lain.

Menurut Jogiyanto (2007), manfaat dari melakukan go public diantaranya adalah: a. Kemudahan meningkatkan modal di masa mendatang. b. Meningkatkan likuiditas bagi pemegang saham. c. Nilai pasar perusahaan diketahui. Disamping manfaat yang diperoleh perusahaan melalui go public, terdapat beberapa kerugian go public, diantaranya adalah: a. Biaya laporan meningkat. b. Pengungkapan (disclosure) informasi kepada publik maupun pesaing. c. Ketakutan untuk diambil alih.

Istilah underpricing digunakan untuk menggambarkan perbedaan harga antara harga penawaran saham di pasar primer dan harga saham di pasar sekunder pada hari pertama (Beatty, 1989). Menurut Hanafi (2004), underpricing merupakan fenomena yang sering dijumpai dalam IPO. Ada kecenderungan bahwa harga penawaran di pasar perdana selalu lebih rendah dibandingkan dengan harga penutupan pada hari pertama diperdagangkan di pasar sekunder. Sedangkan overpricing yang disebut juga underpricing negatif, merupakan kondisi dimana harga penawaran perdana lebih tinggi daripada harga penutupan hari pertama di pasar sekunder.

Suatu penjelasan mengenai fenomena underpricing adalah adanya asimetri informasi. De Lorenzo dan Fabrizio (2001) menyatakan hampir semua penelitian terdahulu menjelaskan terjadinya underpricing sebagai akibat dari adanya asimetri dalam distribusi informasi antara pelaku IPO yaitu perusahaan, underwriter, dan investor. Bagi perusahaan (emiten), underpricing dapat merugikan emiten karena dana yang dikumpulkan tidak maksimal. Namun, underpricing dapat dijadikan strategi pemasaran untuk meningkatkan minat investor berinvestasi dalam saham IPO dengan memberikan initial return yang tinggi.

Menurut Beatty (1989) asimetri informasi dapat terjadi antara perusahaan emiten dengan underwriter (Model Baron) atau antara informed investor dengan uninformed investor (Model Rock). Pada model Baron (1982) penjamin emisi (underwriter) dianggap memiliki informasi tentang pasar yang lebih lengkap daripada emiten sedangkan terhadap calon investor, penjamin emisi memiliki informasi yang lebih lengkap tentang kondisi emiten. Semakin besar asimetri informasi yang terjadi maka semakin besar risiko yang dihadapi oleh investor, dan semakin tinggi initial return yang diharapkan dari harga saham.

Model Rock (1986) menyatakan bahwa asimetri informasi terjadi pada kelompok informed investor dengan 
uninformed investor. Informed investor yang memiliki informasi lebih banyak mengenai perusahaan emiten akan membeli saham-saham IPO jika harga pasar yang diharapkan melebihi harga perdana. Sementara kelompok uninformed karena kurang memiliki informasi mengenai perusahaan emiten, cenderung melakukan penawaran secara sembarangan baik pada saham-saham IPO yang underpriced maupun overpriced. Akibatnya kelompok uninformed memperoleh proporsi yang lebih besar dalam saham IPO yang overpriced. Menyadari bahwa mereka menerima saham-saham IPO yang tidak proporsional, maka kelompok uninformed akan meninggalkan pasar perdana. Agar kelompok ini berpartisipasi dalam pasar perdana dan memungkinkan mereka memperoleh return saham yang wajar serta dapat menutup kerugian dari pembelian saham yang overpriced, maka saham-saham IPO harus cukup underpriced.

Ukuran perusahaan (SIZE) dapat digunakan sebagai proksi ketidakpastian terhadap keadaan perusahaan dimasa yang akan datang. Terdapat bermacammacam kriteria untuk mengukur besar kecilnya perusahaan misalnya jumlah omset penjualan, jumlah produk, modal perusahaan dan total aktiva. Titman dan Wessels (1988), menyatakan logaritma natural dari total aktiva dan logaritma natural dari total penjualan dapat digunakan sebagai indikator ukuran perusahaan. Total aktiva dianggap mampu menunjukkan ukuran perusahaan karena mewakili kekayaan perusahaan baik berupa aktiva tetap maupun aktiva lancar (Carter dan Manaster, 1990). Ukuran perusahaan dapat diketahui dari besarnya total aktiva perusahaan pada periode terakhir sebelum perusahaan melakukan penawaran saham perdananya.

Ukuran perusahaan yang besar mengindikasikan bahwa perusahaan dalam keadaan yang stabil (Dianingsih, 2003). Menurut Siregar dan Utama (2006), semakin besar ukuran perusahaan, informasi yang tersedia untuk investor dalam pengambilan keputusan sehubungan dengan investasi saham semakin banyak. Beatty (1989) mengemukakan bahwa ukuran perusahaan berpengaruh signifikan dan negatif pada tingkat underpricing. Hal ini menunjukkan bahwa ukuran perusahaan dijadikan proksi tingkat ketidakpastian karena perusahaan besar umumnya lebih dikenal oleh masyarakat daripada perusahaan kecil. Karena lebih dikenal maka informasi mengenai perusahaan besar lebih banyak dibandingkan perusahaan kecil. Hal ini akan mengurangi asimetri informasi pada perusahaan besar sehingga akan mengurangi tingkat underpricing daripada perusahaan kecil karena penyebaran informasi perusahaan kecil belum begitu banyak.

Proporsi saham yang ditawarkan dapat digunakan sebagai proksi terhadap faktor ketidakpastian yang akan diterima oleh investor. Hal tersebut telah dikemukakan oleh Nurhidayati dan Indriantono (1998). Proposi dari saham yang ditahan dari pemegang saham lama dapat menunjukan aliran informasi dari saham emiten ke calon investor. Semakin besar proporsi saham yang dipegang oleh pemegang saham lama semakin banyak informasi privat yang dimiliki oleh pemegang saham lama.

Return on Equity (ROE) adalah perbandingan antara laba bersih dengan total ekuitas yang dimiliki oleh perusahaan. Rasio ini menunjukkan kemampuan perusahaan dalam mengelola ekuitas untuk menghasilkan laba. 
Informasi ROE perusahaan penting bagi investor untuk digunakan sebagai pertimbangan berinvestasi.

ROE merupakan salah satu rasio profitabilitas, yaitu rasio yang menunjukkan seberapa efektifnya perusahaan beroperasi sehingga menghasilkan keuntungan atau laba bagi perusahaan. ROE digunakan untuk mengukur efektifitas perusahaan dalam menghasilkan keuntungan dengan cara memanfaatkan ekuitas yang dimilikinya. Nilai ROE yang semakin tinggi akan menunjukkan bahwa perusahaan mampu menghasilkan laba di masa yang akan datang dan laba merupakan informasi penting bagi investor sebagai pertimbangan dalam menanamkan modalnya.

$$
\text { ROE }=\frac{\text { Laba Bersih Setelah Pajak }}{\text { Jumlah Ekuitas }}
$$

Earning per Share (laba per saham) yang dibagikan merupakan salah satu informasi penting bagi investor di pasar modal untuk pengambilan keputusan investasinya. EPS merupakan pendapatan bersih yang tersedia bagi saham biasa yang beredar. Jadi, EPS menggambarkan jumlah rupiah yang diperoleh untuk setiap lembar saham biasa atau laba bersih per lembar saham biasa. Menurut Mainingrum (2005) EPS berpengaruh negatif terhadap saham, karena EPS yang tinggi mengindikasikan kinerja perusahaan yang baik. Menurut Ang (1997) Earning Per Share (EPS) merupakan perbandingan antara laba bersih setelah pajak pada satu tahun buku dengan jumlah saham yang diterbitkan (Outstanding Shares).

DER menunjukkan kemampuan perusahaan dalam membayar hutangnya dengan equity yang dimilikinya (Tambunan, 2007). Menurut Kim et al. (1993), secara teoritis, DER menunjukkan risiko suatu perusahaan dan kondisi ketidakpastian. Apabila DER tinggi, berarti risiko suatu perusahaan tinggi sehingga para investor akan mempertimbangkan hal ini dalam melakukan keputusan investasi (Trisnawati, 1998). Semakin besar DER suatu perusahaan, akan menimbulkan ketidakpastian harga saham perdana yang besar pula, yang pada akhirnya akan mempengaruhi underpricing .

Firth dan Smith

menjelaskan bahwa tingkat kewajiban tinggi menjadikan pihak manajemen perusahaan menjadi lebih sulit dalam membuat prediksi jalannya perusahaan ke depan. DER diukur dengan persentase dari total hutang terhadap ekuitas perusahaan pada saat perusahaan melakukan penawaran perdana.

Inflasi adalah suatu proses meningkatnya harga-harga secara umum dan terus-menerus berkaitan dengan mekanisme pasar yang dapat disebabkan oleh berbagai faktor, antara lain konsumsi masyarakat yang meningkat, berlebihnya likuiditas di pasar yang memicu konsumsi atau bahkan spekulasi, sampai termasuk juga akibat adanya ketidaklancaran distribusi barang.

Inflasi merupakan proses dari suatu peristiwa, bukan tinggi-rendahnya tingkat harga. Artinya, tingkat harga yang dianggap tinggi belum tentu menunjukan inflasi. Inflasi adalah indikator untuk melihat tingkat perubahan, dan dianggap terjadi jika proses kenaikan harga berlangsung secara terus-menerus dan saling pengaruh-memengaruhi. Istilah inflasi juga digunakan untuk mengartikan peningkatan persediaan uang yang kadangkala dilihat sebagai penyebab meningkatnya harga.

Inflasi dapat digolongkan menjadi empat golongan, yaitu inflasi ringan, sedang, berat, dan hiperinflasi. Inflasi ringan terjadi apabila kenaikan harga berada di bawah angka 10\% setahun; 
inflasi sedang antara 10\%-30\% setahun; inflasi berat antara 30\%-100\% setahun; dan hiperinflasi atau inflasi tak terkendali terjadi apabila kenaikan harga berada di atas $100 \%$ setahun.

Tingkat suku bunga merupakan persentase dari modal yang dipinjam dari pihak luar atau tingkat keuntungan yang didapatkan oleh penabung di Bank atau tingkat biaya yang dikeluarkan oleh investor yang menanamkan dananya pada saham. Dalam hal ini, pihak yang berhak menentukan besaran tingkat suku Bunga di Indonesia adalah Bank Indonesia (BI), sehingga tingkat suku bunga ini dinamakan dengan $\mathrm{BI}$ rate.

Menurut teori klasik, bunga adalah bagian dari penggunaan dana yang tersedia untuk dipinjamkan (Loanable Fund). Harga ini terjadi di pasar dana investasi, ini terjadi dimana pada periode waktu tertentu anggota masyarakat memilki kelebihan dari pendapatan kemudian menabung kelebihan pendapatannya. Terdapat dua pandangan berbeda mengenai faktorfaktor yang mempengaruhi tingkat suku bunga (Sukirno, 1994:33): a. Menurut pandangan ahli ekonomi klasik, tingkat bunga dipengaruhi oleh permintaan atas tabungan oleh para investor dan penawaran tabungan oleh rumah tangga. b. Menurut pandangan Keynes, tingkat bunga dipengaruhi oleh jumlah uang yang beredar dan preferensi liquiditas atau permintaan uang. Preferensi liquiditas adalah permintaan terhadap uang seluruh masyarakat dalam perekonomian.

Dalam hubungannya dengan permintaan uang, tingkat bunga bisa dibedakan menjadi dua yaitu tingkat bunga dalam negeri dan tingkat bunga luar negeri. Perbedaaan tingkat bunga diantaranya disebabkan beberapa faktor yaitu (Sukirno, 2000:385): a. Perbedaan risiko, pinjaman pemerintah membayar tingkat bunga yang lebih rendah dari pada tingkat bunga pinjaman swasta karena resikonya lebih kecil. b. Jangka waktu pinjaman, semakin lama waktu pinjaman semakin besar tingkat bunga. c. Biaya administrasi pinjaman, pinjaman yang lebih sedikit jumlahnya akan membayar tingkat bunga yang lebih tinggi.

\section{METODE PENELITIAN}

Metode yang digunakan dalam penelitian ini adalah metode kuantitatif. Metode ini menggunakan analisis regresi berganda sebagai cara untuk mengukur pengaruh variabel-variabel independen yaitu ukuran perusahaan, persentase saham yang ditawarkan, Earning per Share (EPS), Return on Equity (ROE), Debt to Equity Ratio (DER), tingkat inflasi, dan tingkat suku bunga (BI rate) terhadap variabel dependen yaitu tingkat underpricing.

Populasi dalam penelitian ini adalah seluruh perusahaan manufaktur yang melakukan Initial Public Offering (IPO) selama periode Januari 1996 hingga Desember 2015. Dari kategori populasi tersebut didapatkan jumlah populasi sebanyak 57 Perusahaan. Selanjutnya, pengambilan sampel data dilakukan dengan metode purposes sampling dengan kriteria sebagai berikut: a. Perusahaan IPO yang sahamnya underpriced. $b$. Tersedia prospektus saham saat melakukan IPO yang memuat informasi mengenai laporan keuangan perusahaan, ukuran perusahaan, dan jumlah lembar saham yang ditawarkan.

Berdasarkan pada sumber datanya, data yang dipakai di dalam penelitian ini adalah data sekunder, yaitu data yang diperoleh peneliti dari sumber yang sudah ada, dan tidak dikumpulkan langsung oleh peneliti (Suyono, 2003). Sumber data yang digunakan antara lain: a. Prospektus Final 
dari perusahaan-perusahaan yang go public dari tahun 1996-2015 untuk mendapatkan data terkait laporan keuangan perusahaan, ukuran perusahaan, dan jumlah lembar saham yang ditawarkan. b. Indonesia Stock Exchange Fact Book untuk mendapatkan data perusahaan-perusahaan yang go public pada periode tahun 1996-2015. c. Indeks Harga Saham Individu untuk mendapatkan data pergerakan harga saham perusahaan yang go public pada periode tahun 1996-2015. d. Persentase besaran inflasi dan suku bunga (BI rate) di Indonesia yang didapat dari www.bi.go.id.

Teknik analisis data yang digunakan adalah dengan cara analisis linier berganda.

\section{HASIL DAN PEMBAHASAN}

Uji $F$ dilakukan untuk menguji secara keseluruhan pengaruh variabel bebas terhadap variabel terikat. Dengan kriteria pengujiannya adalah: jika $F_{\text {hitung }}$ $>F_{\text {tabel }}$ atau sig. $<\alpha(0,05)$, maka hal ini berarti variabel bebas mampu menjelaskan variabel terikat secara bersama-sama. Jika $F_{\text {hitung }}<$ Ftabel atau sig. $>\alpha$, maka hal ini berarti variabel bebas secara bersama-sama tidak mampu menjelaskan variabel terikatnya. Bahwa hasil sebesar 2,137 yang signifikan pada 0,074 . Jadi sig $0,074>0,05$. Hal ini berarti bahwa seluruh variabel independen yang digunakan pada penelitian ini secara bersama-sama tidak mempengaruhi nilai variabel dependen (Underpricing).

Uji $\mathrm{t}$ dilakukan untuk mencari pengaruh variabel bebas terhadap variabel terikat dalam persamaan regresi secara parsial dengan mengasumsikan variabel lain dianggap konstan. Uji $t$ dilakukan dengan membandingkan antara nilai $t$ yang dihasilkan dari perhitungan statistik dengan nilai $t_{\text {tabel }}$.
Dapat juga dilihat dari nilai signifikansi. Jika sig $<0,05$ maka variabel tersebut secara parsial mempengaruhi nilai variabel dependen (Underpricing) Untuk mengetahui nilai $t_{\text {hitung }}$

Ukuran Perusahaan (LNSIZE) memiliki nilai $t_{\text {hitung }}$ sebesar 0,391 dan signifikansi 0,699 (> 0,05), dengan demikian LNSIZE berpengaruh positif tidak signifikan terhadap variabel dependen. Persentase Saham yang Ditawarkan (PSD) memiliki nilai $t_{\text {hitung }}$ sebesar -0,787 dan signifikansi 0,438 (> 0,05), dengan demikian PSD berpengaruh negatif tidak signifikan terhadap variabel dependen. Earning per Share (EPS) memiliki nilai $t_{\text {hitung }}$ sebesar $-0,229$ dan signifikansi $0,820 \quad(>0,05)$, dengan demikian EPS berpengaruh negatif tidak signifikan terhadap variabel dependen. Return on Equity (ROE) memiliki nilai $t_{\text {hitung }}$ sebesar $-1,187$ dan signifikansi 0,245 (> 0,05), dengan demikian ROE berpengaruh negatif tidak signifikan terhadap variabel dependen. Debt to Equity Ratio (DER) memiliki nilai $t_{\text {hitung }}$ sebesar 2,441 dan signifikansi 0,021 (< 0,05), dengan demikian DER berpengaruh positif signifikan terhadap variabel dependen. BI Rate (BIR) memiliki nilai $\mathrm{t}_{\text {hitung }}$ sebesar 0,849 dan signifikansi 0,403 (> 0,05), dengan demikian BIR berpengaruh positif tidak signifikan terhadap variabel dependen. Tingkat Inflasi (INF) memiliki nilai $t_{\text {hitung }}$ sebesar $-0,603$ dan signifikansi 0,552 (> 0,05), dengan demikian INF berpengaruh negatif tidak signifikan terhadap variabel dependen.

Koefisien determinasi $\left(R^{2}\right)$ menunjukkan proporsi yang diterangkan oleh variabel independen dalam model terhadap variabel terikatnya, sisanya dijelaskan oleh variabel lain yang tidak dimasukkan dalam model, formulasi model yang keliru dan kesalahan eksperimen. Dapat diketahui bahwa nilai 
Adjusted R2 yang diperoleh sebesar 0,190 . Ini berarti bahwa tingkat underpricing perusahaan manufaktur yang melakukan IPO tahun 1995 - 2015 dipengaruhi oleh variabel bebasnya yaitu Ukuran Perusahaan (SIZE), Persentase Saham yang Ditawarkan (PSD), Earning per Share (EPS), Return on Equity (ROE), Debt to Equity Ratio (DER), Tingkat Inflasi (INF), dan BI Rate (BIR) sebesar $19 \%$. Sisanya $81 \%$ ditentukan oleh variabel lain yang tidak dianalisis dalam penelitian ini.

Model regresi berganda dalam penelitian ini digunakan untuk menyatakan hubungan fungsional antara variabel bebas dan variabel terikat. Berdasarkan hasil bahwa dapat dirumuskan persamaan regresi linear berganda sebagai berikut: $\mathrm{UP}=-18,948$ + 415,782 (LNSIZE) - 0,789 (PSD) 2,206 (EPS) - 0,180 (ROE) + 4,045 (DER) - 0,786 (INF) + 2,082 (BIR) Angka yang dihasilkan dari pengujian tersebut dijelaskan sebagai berikut: Konstanta. Nilai konstanta yang diperoleh sebesar -18,948. Hal ini mengindikasikan bahwa jika variabel independen bernilai nol, maka besarnya tingkat underpricing adalah $-18,948$ satuan. Koefisien Regresi SIZE. Nilai koefisien regresi Ukuran Perusahaan (SIZE) sebesar 415,782. Hal ini menunjukkan bahwa setiap kenaikan satu satuan Ukuran Perusahaan akan mengakibatkan kenaikan terhadap tingkat underpricing sebesar 415,782. Koefisien Regresi PSD. Nilai koefisien regresi Persentase Saham yang Ditawarkan (PSD) sebesar -0,789. Hal ini menunjukkan bahwa setiap kenaikan satu satuan Persentase Saham yang Ditawarkan akan mengakibatkan penurunan terhadap tingkat underpricing sebesar -0,789. Koefisien Regresi EPS. Nilai koefisien regresi Earning per
Share (EPS) sebesar 2,206. Hal ini menunjukkan bahwa setiap kenaikan satu satuan Earning per Share akan mengakibatkan kenaikan terhadap tingkat underpricing sebesar 2,206. Koefisien Regresi ROE. Nilai koefisien regresi Return on Equity (ROE) sebesar -0,180. Hal ini menunjukkan bahwa setiap kenaikan satu satuan Return on Equity akan mengakibatkan penurunan terhadap tingkat underpricing sebesar -0,180. Koefisien Regresi DER.Nilai koefisien regresi Debt to Equity Ratio (DER) sebesar 4,045. Hal ini menunjukkan bahwa setiap kenaikan satu satuan Debt to Equity Ratio akan mengakibatkan kenaikan terhadap tingkat underpricing sebesar 4,045. Koefisien Regresi INF. Nilai koefisien regresi Tingkat Inflasi (INF) sebesar -0,786. Hal ini menunjukkan bahwa setiap kenaikan satu satuan Tingkat Inflasi akan mengakibatkan penurunan terhadap tingkat underpricing sebesar $-0,786$. Koefisien Regresi BIR. Nilai koefisien regresi BI Rate (BIR) sebesar 2,082. Hal ini menunjukkan bahwa setiap kenaikan satu satuan BI Rate akan mengakibatkan kenaikan terhadap tingkat underpricing sebesar 2,082.

\section{KESIMPULAN DAN SARAN}

Berdasarkan hasil analisis yang telah diuraikan pada bagian sebelumnya, maka kesimpulan yang dapat diambil adalah: 1. Ukuran perusahaan (SIZE) tidak berpengaruh signifikan terhadap tingkat underpricing perusahaan manufaktur yang IPO pada periode 1996-2015. 2. Persentase Saham yang Ditawarkan (PSD) tidak berpengaruh signifikan terhadap tingkat underpricing perusahaan manufaktur yang IPO pada periode 1996-2015. 3. Earning per Share (EPS) tidak berpengaruh signifikan terhadap tingkat underpricing perusahaan manufaktur yang IPO pada 
periode 1996-2015. 4. Return on Equity (ROE) tidak berpengaruh signifikan terhadap tingkat underpricing perusahaan manufaktur yang IPO pada periode 19962015. 5. Debt to Equity Ratio (DER) berpengaruh positif signifikan terhadap tingkat underpricing perusahaan manufaktur yang IPO pada periode 19962015. 6. Tingkat Inflasi (INF) tidak berpengaruh signifikan terhadap tingkat underpricing perusahaan manufaktur yang IPO pada periode 1996-2015. 7. BI Rate (BIR) tidak berpengaruh signifikan terhadap tingkat underpricing perusahaan manufaktur yang IPO pada periode 19962015. 8. Seluruh variabel independen secara bersama-sama tidak berpengaruh terhadap tingkat underpricing perusahaan manufaktur yang IPO pada periode 19962015.

Adapun saran-saran yang dapat diberikan terkait keterbatasan pada penelitian ini untuk kepentingan penelitian selanjutnya yaitu: 1. Menggunakan informasi keuangan lainnya selain EPS, ROE, dan DER. Menggunakan informasi non keuangan lainnya selain Ukuran perusahaan dan persentase saham yang ditawarkan. Menggunakan variabel makroekonomi lainnya selain tingkat inflasi dan BI Rate sebagai variabel independen penelitian. 2. Menggunakan perusahaan dari jenis industri lain untuk dapat dibandingkan dengan perusahaan dari industri manufaktur. 3 . Memperpanjang masa periode penelitian agar mendapatkan sampel penelitian yang lebih banyak untuk hasil penelitian yang lebih valid.

\section{DAFTAR PUSTAKA}

Ang, Robert. 1997. Pintar Pasar Modal Indonesia. Jakarta: Mediasoft Indonesia.

Beatty, R. P. dan Ritter, J. R. 1986. Investment Banking, Reputation, and the Underpricing of Initial Public Offerings. Journal of Financial Economic, Vol. 15, No. 213-232.

Daljono. 2000. Analisa Faktor-faktor yang Mempengaruhi Initial Return Saham yang Listing di BEJ Tahun 1990-1997. Makalah Seminar, Seminar Nasional Akuntansi III. Depok.

Darmadji, T. dan Fakhruddin, H. 2001. Pasar Modal di Indonesia, Pendekatan Tanya Jawab. Jakarta: Salemba Empat.

Dyah Ratih Suliastuti. 2006. Saham \& Obligasi (Ringkasan Teori dan Soal Jawab), Edisi Pertama, Cetakan Kedua. Yogyakarta: Universitas Atma Jaya.

Eduardus Tandelilin. 2010. Portofolio dan Investasi - Teori dan Aplikasi, Edisi Pertama. Yogyakarta: Kanisius.

Fahmi, Irham. 2012. Analisis Kinerja Keuangan Panduan Bagi Akademisi, Manajer, dan Investor untuk Menilai dan Menganalisis Bisnis dari Aspek Keuangan. Bandung: Alfabeta.

Han-da, P. 2010. Strategic Investor and IPO Underpricing: Chinese Evidence. Asian Pacific Science 
and Culture Journal. Vol. 1, No. 22-33.

Kim, Keneth, A. and Hyun Shan Shin. 2001. The Underpricing of Seasoned Equity Offering: 1983:1998.

Mohamad Samsul. 2015. Pasar Modal dan Manajemen Portofolio (Edisi 2). Jakarta: Erlangga.

Penman, Stephen H. 2010. Financial Statement Analysis and Security Valuation $\left(4^{\text {th }}\right.$ Edition $)$. International Edition, Mc. GrawHill.

Prihadi, Toto. 2011. Analisis Laporan Keuangan (Cetakan Kedua). Penerbit PPM.

Sandhiaji, Bram Nugroho. 2004. Analisis

Faktor-Faktor yang

Mempengaruhi Tingkat

Underpricing pada Penawaran Umum Perdana (IPO) Periode Tahun 1996-2002. Universitas Diponegoro, Semarang.
Sutrisno, dkk. 2000. Pengaruh Variabel Fundamental dan Teknikal terhadap Harga Saham. (Jurnal)

Tambunan, Andi Porman. 2007. Menilai Harga Saham Wajar, Cetakan ke7. Jakarta: PT Elex Media Komputindo.

Titman and Wessels. 1988. The Determinants of Capital Structure Choice. The Journal of Finance, Vol. 43, No. 1. March. pp. 1-19.

Yolana, Chastina, dan Martani, Dwi. 2005. Variabel-variabel yang Mempengaruhi Fenomena Underpricing pada Penawaran Saham Perdana di BEJ Tahun 1994-2001. Makalah Seminar, Seminar Nasional Akuntansi VIII. Solo. 